\title{
Moral Argument and the Justification of Policy: New Labour's Case for Welfare Reform
}

This article proposes a framework for exploring how politicians use moral arguments to win support for their policies. It proceeds from the premise that the formulation of such arguments is mediated by three factors that constitute a general context of justification - 'ideology,' 'argumentation' and 'hegemonic competition.' For analytical purposes, the framework reconstructs the process of justification as one in which argumentative strategies are selected, modified and utilised in the light of these factors. The framework is applied to New Labour's case for the New Deals and Flexible New Deal. The analysis reveals that these initiatives and the moral arguments used to promote them are broadly consistent with New Labour's ideology; the arguments are appropriate to the policies; and that New Labour succeeded in setting the agenda on welfare reform.

\section{Introduction}

The justification of policy is an integral part of democratic politics. From the annual party conference to the House of Commons, a television interview, or a general election manifesto, politicians seek to win support for their party's legislative and policy programme in a variety of settings. There is a range of justificatory strategies available and a politician may attempt to sell a policy by claiming, for instance, that it is justified on pragmatic grounds, by reference to tradition, or perhaps because public opinion demands it (Cook, 1980, 514-516). The stakes involved are high, as a wellchosen argument can ensure the successful passage of legislation through Parliament 
or help to secure an election victory. To maximise its chances of success, a party must consider a number of factors when formulating an argumentative strategy to promote a new policy initiative. They include the history of the policy area or programme, the need for consistency between their chosen argument and the party's core values, the prevailing political climate, and the audience they will address. By the same token, scholars must take these same factors into consideration if they are to supply a full account of the dynamics of political justification.

Politicians often appeal to moral principles and arguments in their efforts to sell new policy programmes. Thus, they typically make the case for initiatives in the area of welfare by reference to the increase in well-being - or, more generally, the positive consequences - the policy will produce, and they frequently invoke human rights or liberties when seeking to persuade people to back constitutional reforms. The promotion of community responsibilities, meanwhile, is most often justified by reference to the fostering of civic virtue and the common good. It is important to note, however, that in making arguments of this kind, politicians are not seeking to claim that a policy is morally right in the sense that it fulfils the criteria supplied by a particular moral theory. Rather, their goal is to achieve a consensus in the policy area concerned, and moral arguments - used in conjunction with various rhetorical strategies - can enable them to do so. With this in mind, the article examines moral argument from the perspective of politics rather than through the lens of moral philosophy, and thus seeks to offer a 'politicised' conception of moral argument.

Given the prevalence of moral language in contemporary political argument, it is surprising that its role in making the case for policy initiatives has to date received 
little attention from scholars. Therefore, the primary task of this article is to facilitate exploration of this hitherto neglected area by proposing a theoretical framework that will enable us to disaggregate and reconstruct the process by which politicians select, formulate and employ moral arguments within a democratic context. To demonstrate the utility of this approach, the article brings the framework to bear on New Labour's moral arguments for its welfare reforms.

\section{Towards an Understanding of the Dynamics of Moral Argument in Politics}

A core assumption of this article is that the formulation of moral arguments is mediated by three factors, which constitute a general 'context of justification' - a context of ideology, a context of argumentation, and a context of hegemonic competition. ${ }^{1}$ The key themes within the 'context of ideology' are the 'morphological' character of ideology, and the process of 'decontestation,' by which meaning is assigned to its constituent concepts. Meanwhile, the 'context of argumentation,' within which moral principles may be utilised in political arguments, is concerned with the question of how the different requirements of argumentation in various policy areas may influence the choice of justificatory strategy. Finally, the 'context of hegemonic competition' addresses the issue of how political parties secure advantage over their opponents in rhetorical competitions. I now outline these three elements in turn.

In his theory of ideological morphology, Freeden proposes that an ideology consists of a cluster of core concepts, a number of adjacent concepts, and a periphery composed of ideas that are insignificant relative to the core $(1996,77)$. These 
concepts are given meaning through the process of decontestation, by which each is rotated 'through a range of meanings until one of those meanings is held vis-⿳亠丷⿵冂-vis the similarly held, or decontested, meanings of every other concept' (Freeden, 1996, 83). In this way, a coherent, integrated ideological platform is generated. Policy proposals are located on the perimeter of an ideology and link its constituent concepts to the social world (Freeden, 1996, 79-80). Politicians often promote these proposals by appealing to moral arguments, which should themselves be as consistent as possible with both the policy proposal concerned and the decontested meanings of the ideology's constituent concepts. Such consistency is attainable through cultural adjacency, which avoids logical criticism by 'creating [culturally] acceptable connections between terms and arguments' (Freeden, 1996, 85). Hence, the requirements of argumentation can supply further reference points for decontestation.

The 'context of argumentation' encompasses the three main traditions of Western moral philosophy, namely consequentialism, deontology and virtue theory. Because this article examines moral argument from a political - as opposed to a philosophical - perspective, it is important to note that there are differences in how moral philosophers characterise these paradigms and how politicians employ them to win support for their policies. Thus, I will provide the standard definitions of the three theories that are acceptable to moral philosophers, before giving examples of the broader way in which actual politicians use them.

As Scheffler explains, consequentialism states that the rightness of an act is determined by whether it maximises well-being, as judged from an impartial perspective that gives equal consideration to the interests of all $(1988,1)$. In a 
political context, this mode of argumentation is typically used in the area of welfare, where politicians emphasise the increase in - though not necessarily the maximisation of - well-being a policy will produce or, more generally, its positive consequences. A case in point is New Labour's ongoing campaign to encourage people to give up smoking to improve their own health and that of others (Department of Health, 2007). Contemporary deontology, meanwhile, emphasises natural rights, the result of which is that 'the language of rights has become a well-established part of popular moral discourse'. These rights are accompanied by obligations, which people must accept in exchange for the privilege of exercising their rights (Scarre, 1996, 12). Deontological reasoning frequently appears in politicians' arguments to promote constitutional reforms such as the Human Rights Act of 1998, a measure New Labour claimed would protect and uphold the human rights of every UK citizen (Labour Party, 2005, 111). Finally, virtue theory emphasises the 'virtuous individual and on those inner traits, dispositions, and motives that qualify her as being virtuous' (Slote, 1997, 177). Politicians often employ this form of moral argument to sell policies relating to community, an example being the introduction of citizenship education to the National Curriculum in 2002 (Atkins, 2008, 134). For New Labour, this initiative would both inculcate civic virtues in children and promote the common good through the creation of a 'healthy national political culture' (Landrum, 2002, 221).

Finally, the 'context of hegemonic competition' invites consideration of how the desire to win rhetorical competitions may further influence the selection and modification of argumentative strategies. Thus, a party may choose a particular strategy because it appeals to the commonsense intuitions of the electorate, or because it offers the best available means of undermining the arguments of an 
opponent. An argument may also be selected because it is logically and/or culturally consistent with the party's ideological commitments, and hence is more likely to be convincing than one that contradicts them. Politicians enhance the effectiveness of their justificatory strategies with a range of rhetorical devices (see inter alia Myers, 2000; Charteris-Black, 2005; Finlayson, 2007), and an examination of these techniques will enable us to take into account the 'emotional as well as the intellectual attractiveness of arguments' (Freeden, 1996, 37).

Using this understanding of the 'context of justification' as a starting-point, the article offers a three-fold analytical framework, which is applied to investigate the use of moral argument in contemporary politics. The three stages are:

1. An examination of how particular principles and arguments may be made answerable to an integrated ideological platform.

2. An examination of how particular forms of argument may be deployed compellingly with respect to specific types of policy.

3. An examination of how argumentative strategies may be formulated in ways that provide an opportunity to secure hegemonic advantage in a competitive, rhetorical political situation.

Although there may be grounds for thinking the 'context of ideology' is more fundamental than the other contexts, they may in practice rebound back on each other. Thus, the process outlined here is neither linear nor hierarchical, and a clear explanation of the strategic decision-making process underlying the justification of policy is possible only when all three stages have been considered. It is also worth noting that these stages do not represent the procedure by which actual politicians choose particular moral principles and arguments. Rather, they form analytical 
strands in a reconstruction of the process by which argumentative strategies are selected, modified and utilised. The framework will therefore enable us to give a nonreductive account of this process, while remaining sensitive to the potentially conflicting considerations that enter into it and are implicit in articulations of moral argument.

In the remainder of this article, I employ the framework to elucidate the procedure by which New Labour formulated and applied moral arguments to sell its welfare reforms. In the following section, I outline the main features of the New Deals and their successor: the Flexible New Deal. Next, I explore the relationship between these initiatives and New Labour's ideological platform. I then consider the moral arguments used to justify them, and I show that these arguments are consistent with both New Labour's ideological commitments and the policies themselves. In the final section, I examine the tactics that New Labour deployed in its efforts to achieve hegemonic advantage in the area of welfare policy.

\section{New Labour's Welfare Reforms}

The primary objective of the New Deals was to enable unemployed people to 'compete effectively for the jobs that are continually being created in Britain's dynamic labour market' (HM Treasury, 2000, 10). This programme was based on a policy framework endorsed by the OECD (Carcillo and Grubb, 2006) that consists of three elements, of which the first is active labour market policies. These initiatives are intended to provide unemployed individuals with help and support that is tailored to meet their needs, and thus will enable them to reconnect with the job market. The 
second element consists of policies designed to 'make work pay,' such as the National Minimum Wage and Tax Credits, while the third comprises initiatives to tackle the barriers that prevent people from returning to work (HM Treasury and DWP, 2003, 2). One such obstacle was the shortage of good quality, affordable of childcare facilities, which New Labour sought to rectify through its National Childcare Strategy. Other barriers include discrimination and poor basic skills, and in April 2002 New Labour introduced Jobcentre Plus to tackle them. This agency provides a range of services, including training and access to childcare, and is intended to be flexible, work-focused and suited to the needs of each individual. The issues involved here are frequently multi-dimensional, so a "partnership approach between a number of Government departments, other public sector bodies, employers and the community and voluntary sectors' is required (HM Treasury and DWP, 2003, 50).

New Labour launched the New Deal for Young People (NDYP) in April 1998. This scheme was targeted at young people aged between 18 and 24 who were receiving Jobseeker's Allowance (JSA). After six months of 'open' unemployment, participants entered a four-month 'gateway' period, in which they were assigned a personal adviser who helps them to acquire 'any needed basic skills (such as punctuality, how to compose a CV, and so forth) and engage in a serious job search' (Waltman, 2009, 126). If, at the end of this phase, they had not found unsubsidised employment, participants had to accept one of four options, the first of which is a subsidised job that included training and lasted for up to six months. To this was later added the opportunity to participate in self-employment 'Test Trading,' during which the young person could 'experience the realities of self-employment while still receiving support and guidance from a provider' (Department for Social 
Development, 2006). The second option was a six-month work experience and training placement with a voluntary organisation, while the third was six months of work experience with an environmental task force, including training. The fourth option was up to 12 months of full-time education for those lacking basic skills, during which JSA continues (Driver and Martell, 2006, 97). After the Options phase, participants who had not found employment entered the 'follow through' period, which offered further guidance and support for up to six months. The programme was mandatory, so 'the receipt of benefit is conditional on willingness to accept offers of work or training. Failure to do so is penalised by loss of benefit' (Shaw, 2007, 47).

According to New Labour, the NDYP was a great success, helping to reduce youth unemployment by 75 per cent. The next step, however, was to address the question of how to help economically inactive individuals into work (Labour Party, 2001, 26). Against the Conservatives, who had neglected this group during their time in government, New Labour argued that although people may be economically inactive due to caring responsibilities or disability, it does not follow that they are uninterested in, or incapable of, work. As a result, 'the benefit system needs to do more to help and encourage people on inactive benefits to return to work' (HM Treasury and DWP, 2003, 49). To this end, New Labour introduced the New Deal for Lone Parents (NDLP) on a national scale in April 1998. This programme was aimed at lone parents whose youngest child is under 16 and who are either unemployed or working for fewer than 16 hours a week. Although participation in the scheme was voluntary, lone parents are required to attend an interview, at which they received 'personal adviser support, help with childcare and training, and financial incentives' (DWP, 2007, 19). Benefit penalties applied if they failed to do so (Clarke, 2007, 159). In 
2006, New Labour proposed to increase the frequency of these interviews to sixmonthly for lone parents whose youngest child is under 11, and to quarterly for those whose youngest child is aged 11 or over (DWP, 2006a, 8). The government subsequently toughened its stance by ending the automatic entitlement to Income Support for lone parents with children aged 12 or over from November 2008, and in October 2010 the qualifying age will fall to seven (DWP, 2007, 44).

New Labour expanded the New Deals to offer voluntary programmes to people on other inactive benefits. The New Deal for Partners was introduced in April 1999 to help the partners of unemployment benefit claimants back into work. It was followed twelve months later by the New Deal 50 Plus, which was aimed at people aged 50 or above who had been in receipt of JSA/Income Support or incapacity benefits for at least six months (Millar, 2000, iv). The next initiative was the New Deal 25+, which was rolled out nationally from April 2001 and targeted people aged 25 and above who had been unemployed for eighteen months or more. Finally, the New Deal for Disabled People was introduced in July 2001 to help incapacity benefit claimants to find work. ${ }^{2}$

In October 2009, New Labour introduced the Flexible New Deal (FND) to replace the NDYP and the ND25+ in some areas. ${ }^{3}$ A second phase will follow in October 2010. Under this scheme, a person's first twelve months on JSA is divided into three stages, during which the support they receive from Jobcentre Plus increases. Correspondingly, participants are required to intensify their efforts to find work (DWP, 2008a, 12-13). After twelve months, jobseekers transfer to the FND, a scheme delivered by private and third sector providers who will give them the 'individual, 
personalised support' they need to enable them to find work (DWP, 2008b, 8). These providers receive payment 'according to how many clients they get into work with significant discretion over how they achieve that goal' (Mulheirn and Menne, 2008, 10). All participants must undertake a minimum of four weeks' work experience during this time, and there are tough sanctions for those who refuse the support offered.

In sum, the New Deals and FND were intended to help individuals from several target groups to find employment, and offered them a range of incentives - such as Tax Credits and the National Minimum Wage - to do so. These policy programmes, which propose a number of means for achieving a specific end, suggest the use of a consequentialist argument.

\section{The Compatibility of New Labour's Welfare Policies and their Supporting} Arguments with its Ideological Platform

The 'context of ideology' invites consideration of whether the arguments New Labour deployed in support of its welfare reforms, and the policies themselves, are congruent with its core ideological commitments. Freeden identifies these concepts as equal worth, opportunity for all, responsibility, social justice, community and cohesion $(1999,48)$, and they have remained remarkably stable throughout New Labour's time in government. As such, they provide a solid basis for this analysis. For Brown and Darling, the New Deals accorded primarily with New Labour's core value of equality of opportunity $(2001, \mathrm{iii})$. This is because a key objective of the scheme was to ensure that the labour market functions well for everyone in Britain, 
and that nobody is prevented from obtaining work because, for instance, they have a disability or have children to look after (HM Treasury and DWP, 2003, 3). New Labour linked this notion of opportunity for all to the values of equal worth and social inclusion, arguing that everyone who is able to work is entitled to have the opportunity to do so, and thus to have a stake in society, regardless of their circumstances (DWP, 2006b, vii). These values are also evident in New Labour's policies to tackle workplace discrimination and to remove other barriers that prevent people from finding employment.

The New Deals and the arguments used to promote them manifested New Labour's commitment to the goal of full employment, decontested as equality of opportunity for all (HM Treasury, 1997, 5). By putting 'work first,' New Labour aimed to Secure social justice for those who too often have been left behind, and to enable them to realise their full potential, to the economic and social benefit of the whole community (Brown and Smith, 2003, $i$ ).

As Driver points out, this strategy to boost the human capital of poorer people by giving them the skills they need to participate in the labour market constituted an attempt to manipulate the distribution of resources. 'In this way,' he argues, 'opportunities are connected, in New Labour thinking, to outcomes' (2004, 32). By enacting policies to give people the opportunity to learn new skills and ultimately to find employment, New Labour sought to realise its goal of a strong, cohesive society in which everyone has a stake (Primarolo, 2004, 3). At the same time, however, the principles of social justice demand that a 'modern, civilised society must protect the most vulnerable within it' (DWP, 2002, 5). To this end, New Labour argued that 
those who are able to work should have the opportunity to enter the job market, while those who are unable to should receive the security they need.

According to Finlayson, a significant development of New Labour's welfare reforms was the "emphasis on the individualisation of service delivery, and with it the encouragement of responsibility for gearing up for the new economy' $(2003,164)$. That is, New Labour intended that participants in the New Deals would act responsibly and accept the opportunities offered, in return for the personalised programme of support and training they received (DWP, 2008b, 5). The core New Labour value of reciprocal rights and responsibilities thus had a strong presence in the New Deals. Indeed, it is explicit in the argument that government has an obligation to provide participants with real opportunities for training and work, while those able to do so have the responsibility to accept these offers - or at least to stop claiming benefits (Layard, 2001, 3).

During its third term in office, New Labour introduced the FND, which is based on the notion of 'opportunity for all and responsibility from all' (DWP, 2008c, 17). Like its predecessor, the FND is intended to make work pay, to which end it introduces new back to work credits, and to help people who can work to find employment while supporting those who cannot. It also seeks to remove the barriers that prevent disadvantaged individuals entering the job market, thereby enabling them to contribute to the nation's prosperity. This active approach to welfare, Hain believes, will realise New Labour's vision of an 'inclusive, cohesive and prosperous society with fairness and social justice at its core' $(2007,3)$. Thus, the values of equal worth, opportunity for all, community, cohesion and social justice are present in the FND. 
A key difference between the two programmes is that the FND imposes greater conditionality on both jobseekers and training providers. For participants, this new approach is summarised as 'more support matched by higher expectations' (DWP, 2008c, 16). As such, they must act responsibly by preparing for, searching for and accepting employment in exchange for the flexible, personalised support they receive. Those who fail to comply with the scheme are subject to a tougher sanctions regime, and there is a new requirement for the long-term unemployed to engage in a programme of full-time work experience (DWP, 2008a, 37). Providers, meanwhile, are motivated to find work for people by the competition for contracts and payment by results (DWP, 2008c, 11). Those who do not meet their targets risk having their contracts terminated early. At first sight, this increased emphasis on reciprocal responsibilities suggests a shift to the right in New Labour's thinking on welfare. However, when we consider the goals of the programme - namely the creation of a fairer, more cohesive community, in which 80 per cent of people are in work and no child is growing up in poverty (Hain, 2007, 3) - it is clear that this shift is in means only; the ends remain recognisably social democratic. ${ }^{4}$

Although the New Deals and FND appear to be consistent with New Labour's ideology, a problem arises when we consider their practical implications. In both schemes, as Hickson correctly points out, the burden of responsibility falls primarily on those at the bottom of society, who New Labour deems to be socially excluded, 'with no corresponding duties, such as the responsibility to pay higher direct taxation, falling on those at the top' $(2004,133)$. This has resulted in the exclusion of the rich (Finlayson, 2010, 15), which violates New Labour's commitment to the values of social justice and community cohesion. It also undermines the value of equal worth, 
on the ground that if every individual matters equally, it follows that no one should be excluded from the reciprocal responsibilities that underpin a strong, cohesive community (Atkins, 2010, 52). There were further disparities between New Labour's arguments for its welfare reforms and their practical effects but, as we will see in the remainder of the article, they did not prevent it from achieving a consensus in this area of policy.

\section{The Moral Arguments Used to Justify New Labour's Welfare Reforms}

As stated above, politicians typically make the case for welfare reforms by reference to the amount of well-being or the positive consequences they will produce. The congruence between consequentialist reasoning (broadly conceived) and the area of welfare policy makes this mode of moral argument particularly suitable for selling such initiatives, and it is therefore unsurprising that a tripartite consequentialist argument constituted the primary case for the New Deals. The first strand of this argument focused on the benefits for participants in the schemes. According to the DWP, exclusion from the labour market can produce a range of negative consequences for individuals, which include loss of daily routine, a sense of purpose, and self-esteem $(2002,1)$. In contrast, work is beneficial because it 'strengthens independence and dignity. It builds family aspirations... and can improve an individual's health and well-being' (DWP, 2006a, 2). Thus, by moving people off benefits and into work, the New Deals were intended to 'transform the lives of millions, by making them self-sustaining rather than dependent - a hand-up not a hand-out' (Layard, 2001, 6). 
The second strand of New Labour's consequentialist argument emphasised the positive effects of the New Deals on society as a whole. New Labour identified areas of the country in which unemployment is higher than average, and claimed that people with disabilities, lone parents and people from minority ethnic groups are often disproportionately concentrated within these regions. Such individuals may experience multiple difficulties, including poor-quality public transport and rising crime, which ultimately lead to social exclusion (DWP, 2006a, 10). The goal of the New Deals was, in the words of Andrew Smith, the former Employment Minister, to promote social inclusion by bringing 'employment, training and benefits to people in the right way, so that they have the standard and quality of life that we want in a civilised society' (Hansard 19 December 1997, col. 627, vol. 303). This would enable people to contribute to - and have a stake in - society, thus benefiting the wider community by breaking the cycle of exclusion, crime and deprivation that blights Britain's poorest neighbourhoods (HM Treasury and DWP, 2003, 50). However, despite their success in reducing unemployment - particularly among the under- $25 \mathrm{~s}$ New Labour's policies had little impact on in-work poverty, a condition linked to such factors as part-time employment, low pay, and a lack of job retention or job progression (Kenway, 2008, 8; Smith and Middleton, 2007, 13). As several studies have shown that people who are in in-work poverty are more likely to experience reduced well-being and social exclusion (see Smith and Middleton, 2007, 71-72), New Labour's linkage of paid employment and social inclusion appears tenuous.

Finally, New Labour emphasised the positive consequences of the New Deals for Britain's economy. This argument proceeded from the premise that people's skills and education are key determinants of productivity growth and economic performance 
(HM Treasury, DWP and DfES, 2004, 7). Hence, the New Deals, which were designed to give people the opportunity to acquire new skills, would allow businesses to flourish and thus promote economic growth. They would also challenge the tradeoff between equality and efficiency that prevailed in the 1980s by simultaneously creating economic prosperity and promoting social justice (Brown, 1994, 19). In practice, however, it was estimated that in 2006 'as many as a third of all adults of working age lacked any recognised skills at all, or were at best low-skilled' (Taylor, 2007, 234). These individuals are more likely to be unemployed or in low-paid jobs, and thus to be socially excluded. If we take this point together with figures which show that UK productivity in 2007 (in terms of GDP per worker) was 7 per cent below that of France and 23 per cent less than that of the US (Office for National Statistics, 2009, 1), then it seems New Labour's attempts to reconcile economic efficiency and social justice failed.

The consequentialist case for the New Deals was supported by a secondary deontological argument, which drew on New Labour's core concept of reciprocal rights and responsibilities. According to Blair, 'everyone able to do so has a clear responsibility to find a job and look after their family' $(2001,2)$. In return, government has an obligation to ensure that they receive the help they need to find suitable training or work. The coercive aspect of the New Deals was designed to ensure that all unemployed people of working age were made aware of their options, and thus would be in a position to take responsibility for themselves. After all, one of the main goals of New Labour's welfare reforms was to tackle the 'culture of dependency' and ensure that 'people should not be free to choose a life on benefit' (Shaw, 2007, 46). 
A further motivation for the compulsory aspect of the New Deals is evident in Darling's statement that New Labour's welfare policies were based on a

Moral case for reform which reflects the duty we owe to our children to build a welfare state fit for their future... If we do nothing these children will not only be born poor, they will live poor, and die poor $(1999,35)$.

Blair's pledge to eradicate child poverty within a generation gave this claim additional force $(1999,1)$, and in the same year his government set targets to reduce child poverty by 25 per cent by $2004-05,50$ per cent by $2010-11$, and eventually to eradicate it by 2020. However, despite some initial progress towards these goals, New Labour failed to meet its first target and - notwithstanding the recession - is still far from achieving its second. Given that at least 50 per cent of children living in poverty in 2008 were in working families, it seems that welfare-to-work schemes alone are not enough to alleviate child poverty, and that an overhaul of the taxation and benefit systems is therefore required (Kenway, 2008, 7-8, 4).

Despite these problems, New Labour continued to argue as if the New Deals had achieved their stated aims, and indeed hailed them as 'the most successful innovation in the history of the UK labour market' (DWP, 2008b, 6). It is unsurprising, then, that the arguments for the FND closely resemble those used to sell the New Deals, with New Labour claiming that this scheme would benefit individuals by improving their well-being, self-esteem, and future prospects. New Labour also argues that the FND will have positive consequences for the community because it will improve the job prospects of those who face the greatest disadvantage, and thus will reduce social exclusion (DWP, 2007, 23, 5). Here, New Labour again neglects the exclusion of the rich, though the emphasis on job retention and progression in the FND, together with 
the introduction of new back to work credits, may help to alleviate in-work poverty (DWP, 2008c, 38).

New Labour's third consequentialist argument for the FND emphasises its benefits for the economy. The DWP maintains that, by improving people's skills, the programme will enable Britain to compete more effectively in the global economy by creating more jobs and more growth $(2007,27)$. This renewed commitment to skills is evident in the introduction of increasingly personalised support and training through the FND, which perhaps constitutes a tacit recognition of the limited success of the New Deals in this area. Finally, the deontological argument for the FND emphasises the increasing obligations that participants in the scheme must accept in exchange for this support, with New Labour asserting that 'for those who are capable of working, there will be no right to a life on benefits' (DWP, 2008a, 12). A tougher sanctions regime underpins the responsibility to find work, while the greater conditionality imposed on training providers is designed to improve the efficacy of the scheme. These changes, claimed the DWP, would set New Labour on course to achieving its targets of an 80 per cent employment rate by 2015, and the eradication of child poverty by 2020 (2008a, 26).

Overall, the prima facie coherence between New Labour's ideology, its moral arguments for its welfare reforms, and the policies themselves, creates an impression of integrity and competence that can be advantageous in rhetorical competitions, and thus constitutes one of New Labour's strategies for securing hegemonic advantage in the area of welfare policy. I examine the 'context of hegemonic competition' next. 


\section{New Labour's Tactics for Securing Hegemonic Advantage}

The key premise of New Labour's case for the New Deals and FND is that the Conservatives' approach to welfare was seriously flawed. Purdy explains that a residual welfare state began to emerge during the Thatcher and Major governments, which provided a 'low-level safety net for the poor, while encouraging the majority of citizens to take care of themselves' $(2000,183)$. In practice, this meant that people received little or no help to find work, and by the mid-1990s, the number claiming inactive benefits had trebled. For New Labour, the Conservatives' passive approach to welfare fostered 'benefit dependency, wasted talent and obstructed opportunity,' and thereby trapped many people in long-term unemployment. This in turn contributed to a sharp increase in child poverty, which had reached 3.4 million by 1997 (DWP, 2008a, 24-25).

However, the Conservatives were not wholly responsible for the growing culture of dependency, which in fact had been a problem since the early 1970s (Waltman, 2009, 123). Although the Thatcher government removed the requirement on benefit claimants to look for work in 1982, the introduction of Restart interviews in 1986 marked the beginning of a more active approach to welfare that would challenge the dependency culture (Freud, 2007, 12). The Major government consolidated this shift by introducing a Contract for Work, under which unemployed people were obliged to accept work if it is available, and by transforming unemployment benefit into JSA. This latter move both strengthened and formalised the connection between seeking work and claiming benefits and incorporated a number of programmes, such as 'restart' and 'job search plus,' which were intended to help people find employment 
(Johnson, 2001: 65). Underpinning these developments was a desire to create a welfare system for a 'self-help society not a help-yourself society' that promoted independence by reconnecting more people with the job market (Major, 1996, 6). The similarities between this approach and New Labour's welfare reforms are striking, and it is therefore misleading to characterise the former as passive. Nonetheless, it proved strategically useful for New Labour to do so, as we will see below.

The consequentialist argument for the New Deals and FND draws on a narrative of welfare under the Conservatives, in which New Labour establishes relations of equivalence between high unemployment, poverty, wasted potential, community breakdown and social injustice. Brown identifies the source of these difficulties as the New Right's belief that 'more inequality was essential to economic growth' (1994, 1), and thus creates a linkage between Thatcherite ideology, economic inefficiency and social problems. As Charteris-Black explains, such an association implies a causal relationship between these phenomena $(2005,97)$, which enables New Labour to hold the Conservatives directly responsible for Britain's ills. In so doing, New Labour deploys the strategy of 'delegitimisation (of the other),' which is intended to undermine and attack an opponent through the use of such techniques as marginalisation, censure, and the presentation of the other in a negative light (Chilton, 2004, 47, parentheses in original).

New Labour also used the technique of legitimisation to make its case for the New Deals. Examples of this strategy include 'positive self-presentation' as manifested in acts of self-justification, and 'self-identification as a source of authority, reason, vision and sanity' (Chilton, 2004, 47). New Labour deployed the latter to present its 
approach as the only viable solution to the problems created by the Conservative governments, with Blair claiming that 'we are the only people who can be trusted to change, reform and modernise the welfare state, because we are the people who believe in it' $(1994,7)$. Here, Blair suggested that the Conservatives had seriously damaged the welfare state because they rejected the values on which it was built. In contrast, New Labour upheld these values, and therefore was uniquely qualified to undertake the necessary reforms. It was on this basis that Blair described the New Deals, which encouraged self-reliance and personal responsibility, as 'the only way forward as we break the old culture which left generations of families trapped in unemployment and poverty' (2001, 2, emphasis added).

The New Deals were one of several initiatives designed to make work pay and help people into employment. To this end, Brown claimed, we need an enabling state, which offers unemployed individuals a means of escaping poverty by 'using the welfare state to foster responsibility and not to substitute for it.' Indeed, he continued, again drawing on the deontological argument, 'our guiding theme is not what the government can do for you but what the government can enable you to do for yourself' $(1994,5)$. This theme is also present in the FND commitment to creating a welfare state that will support people in developing their capabilities, in return for which they ought to act responsibly by taking full advantage of the opportunities offered to them (DWP, 2008a, 29). The notion of enablement is significant, as it implies state intervention in accordance with Old Labour ideals but without the negative connotations of the latter. Thus, New Labour could reassure its followers on the Left that it was acting in accordance with socialist values, while simultaneously avoiding the Thatcherite charge of excessive state interference. 
A key component of New Labour's enabling state is Jobcentre Plus, which delivers an 'active service to help people become independent and move from welfare into work' (HM Treasury and DWP, 2001, 32). Here, the word 'active' creates a link between New Labour's approach and the activation strategies endorsed by the OECD and implemented by such nations as Finland and Norway. These strategies share several features with the New Deals - such as the 'regular reporting and monitoring of work availability and job-search actions,' the focus on mutual responsibility and the use of sanctions to ensure compliance with the programme (OECD, 2007, 208) - that are given renewed emphasis in the FND. By establishing this connection and claiming that the New Deals 'incorporated lessons from... successful labour markets in Europe, especially Scandinavia' (DWP, 2008b, 7), New Labour identifies its approach with the success of other schemes and thus gives its policies greater legitimacy. ${ }^{5}$

The use of the word 'active' also creates an antagonism between the New Deals and FND on the one hand, and the Conservatives' 'passive' approach, which New Labour blamed for encouraging welfare dependency, on the other. In Charteris-Black's terms, this is an example of 'antithesis,' in which a combination of 'sequencing and comparison' is utilised to contrast the Conservatives' eighteen years in government with New Labour's time in office $(2005,7)$. Antithesis is a powerful tool in New Labour's rhetorical arsenal because it allows the party to present itself as offering a positive solution to the economic and social problems that stem from poverty and high unemployment, while portraying the policies of the Thatcher and Major governments as an abject failure. 
In arguing for its welfare reforms, New Labour also invoked the dire consequences that would follow if the issues of restricted opportunity and social deprivation were ignored. Brown, for instance, asserted that unless action was taken to tackle these problems, Britain would 'continue to drift towards a low-wage, low investment, low skills economy... with all the economic and social ills that brings.' In these circumstances, he argued, there would be more low pay, slow economic growth, unemployment and poverty, while Britain's communities would be at risk from the social problems associated with these phenomena (1994, 2; see also HM Treasury and DWP, 2003, 50). This argument is an example of 'emotive coercion,' which can occur when utterances stimulate an emotional response in the listener in order to persuade them of a particular point of view. Thus, an effect of this strand of the consequentialist argument may be to induce fear by 'making truth claims, in the form of predictions, about causal effects' (Chilton, 2004, 118) that could only be avoided by supporting the New Deals. These arguments proved successful, as New Labour won sufficient support to ensure the passage of the New Deals onto the statute book.

In January 2008, the Conservatives published their own proposals for welfare reform. These measures have obvious parallels with the New Deals and FND, with David Cameron adopting New Labour's linkage of opportunity and responsibility, as well as its commitment to 'help those who want to work into sustained employment, and cut benefits for those who refuse to work' (2008: 1-2). Echoing New Labour again, Cameron asserted that the Conservatives' approach would offer some of Britain's 'most deprived citizens the opportunity to live independent and fulfilling lives. Above all, they will help more people contribute to the responsible society I want to achieve' (2008: 2). These similarities indicate that the Conservatives accepted the basic 
assumptions of New Labour's policies, and that New Labour had therefore succeeded in setting the agenda on welfare.

\section{Conclusion}

In conclusion, the application of the theoretical framework elaborated in this article offers insights into New Labour's choice of argumentative strategy for the New Deals and FND. It shows that these programmes and the moral arguments used to sell them are reasonably consistent with New Labour's ideology; that the arguments themselves are appropriate to the policy area; and that New Labour's choice of a primarily consequentialist strategy - supported by a number of rhetorical techniques - enabled it to set the agenda on welfare policy. The framework thus enables us to expose and analyse the process by which politicians select, modify and apply moral arguments in their efforts to win support for their policy programmes. It also allows us, through reference to the imperatives provided by the three aspects of the 'context of justification,' to explain why these argumentative strategies developed as they did.

The utility of the framework goes beyond the case study analysed in this article. It could be applied, for instance, to examine how New Labour uses moral language to win support for policies in other areas, such as constitutional reform and foreign policy. The findings would, when taken together, provide a full account of the justificatory strategies employed by a single political party. Equally, the framework could facilitate an examination of the ways in which other parties use moral arguments to sell policy, thus paving the way for a comparative analysis. It could also provide a starting-point for a study of the modes of moral argument used by 
politicians in democratic societies beyond Britain, though further research may be required beforehand. This comprehensive and widely applicable framework thus provides a means for illuminating the complex and under-theorised process of moral justification in contemporary politics.

An earlier version of this article was presented as part of the working paper seminar series run by the British Politics Research Cluster, POLSIS, University of Birmingham, in March 2009. I thank the participants for their comments, as well as Steve Buckler, Richard North and the three anonymous referees. Support from the ESRC (award no. PTA-030-2005-00628) and the Leverhulme Trust (grant no. F/00 $391 \mathrm{O}-$ How the Leader Speaks) is gratefully acknowledged.

${ }^{1}$ Here, I draw on Buckler's (2007) framework for examining the role of ideas in politics.

${ }^{2}$ These benefits are Severe Disablement Allowance, Income Support with a disability premium, and Incapacity Benefit.

${ }^{3}$ In Northern Ireland, the 'Steps to Work' programme replaced the New Deals from September 2008 (DETI, 2009).

${ }^{4}$ For further discussion of the distinction between ends and means in relation to New Labour, see Plant (2004).

${ }^{5} \mathrm{I}$ am grateful to the second anonymous referee for making this point.

\section{References}

Atkins, J. (2008), 'How Virtue Theoretic Arguments may be used in the Justification of Policy', Politics, 28 (3), 129-137.

Atkins, J. (2010), 'Assessing the Impact of the Third Way' in S. Griffiths and K. Hickson, eds., British Party Politics and Ideology after New Labour (Basingstoke: Palgrave Macmillan), 39-52.

Blair, T. (1994), Speech to the Labour Party Conference, 4 October.

Blair, T. (1999), Beveridge Lecture, 18 March.

Blair, T. (2001), PM's speech to the Christian Socialist Movement at Westminster Central Hall, 29 March.

Brown, G. (1994), Fair Is Efficient - a socialist agenda for fairness (London: Fabian Society).

Brown, G. and Darling, A. (2001), 'Foreword' in HM Treasury and Department for Work and Pensions, The changing welfare state: employment opportunity for all (London: HMSO), iii-iv.

Brown, G. and Smith, A. (2003), 'Foreword' in HM Treasury and Department for Work and Pensions, Full employment in every region (London: HMSO), $i$. 
Buckler, S. (2007), 'Theory, Ideology, Rhetoric: Ideas in Politics and the Case of "Community" in Recent Political Discourse', British Journal of Politics and International Relations, 9 (1), 36-54.

Cameron, D. (2008), 'Foreword,' in Conservative Party, Work for Welfare: REAL welfare reform to help make British poverty history (Policy Green Paper No. 3), 1-2.

Carcillo, S. and Grubb, D. (2006), From Inactivity to Work: The Role of Active Labour Market Policies, DELSA/ELSA/WD/SEM/(2006)5 (Paris: OECD).

Charteris-Black, R. (2005), Politicians and Rhetoric: The Persuasive Power of Metaphor (Basingstoke: Palgrave Macmillan).

Chilton, P. (2004), Analysing Political Discourse: Theory and Practice (Abingdon: Routledge).

Clarke, K. (2007), 'New Labour: family policy and gender' in C. Annesley, F. Gains and K. Rummery, eds., Women and New Labour: Engendering politics and policy? (Bristol: The Policy Press), 155-173.

Cook, T.E. (1980), 'Political Justifications: The Use of Standards in Political Appeals', The Journal of Politics, 42, 511-537.

Darling, A. (1999), 'Rebuilding the welfare state: the moral case for reform' in G. Kelly, ed., Is new Labour working? (London: The Fabian Society), 35-38.

Department of Enterprise, Trade and Investment (2009), 'Labour Market Summary (seasonally adjusted)'. Available online at: http://www.detini.gov.uk/index/detihome-economic-overview.htm (accessed 6 January 2010).

Department of Health (2007), 'Why go Smokefree?' Available online at: http://smokefree.nhs.uk/why-go-smokefree/ (accessed 18 February 2009).

Department for Social Development (2006), 'New Deal for 18 to 24 Year Olds'. Available online at:

http://www.dsdni.gov.uk/ssa/benefit_information/new_deals/new_deal_for_18_to_24 _year_olds.htm (accessed 18 February 2009).

Department for Work and Pensions (2002), Pathways to work: Helping people into employment, Cm 5690 (London: HMSO).

Department for Work and Pensions (2006a), A new deal for welfare: Empowering people to work, Cm 6730 (London: HMSO).

Department for Work and Pensions (2006b), A new deal for welfare: Empowering people to work (Consultation report), Cm 6859 (London: HMSO).

Department for Work and Pensions (2007), In work, better off: next steps to full employment, Cm 7130 (London: HMSO). 
Department for Work and Pensions (2008a), No one written off: reforming welfare to reward responsibility, Public consultation, Cm 7363 (London: TSO).

Department for Work and Pensions (2008b), Transforming Britain's labour market: Ten years of the New Deal (London: DWP).

Department for Work and Pensions (2008c), Raising expectations and increasing support: reforming welfare for the future, Cm 7506 (London: HMSO).

Driver, S. (2004), 'North Atlantic drift: welfare reform and the "Third Way" politics of New Labour and the New Democrats' in S. Hale, W. Leggett and L. Martell, eds., The Third Way and beyond: Criticisms, futures, alternatives (Manchester: Manchester University Press), 31-47.

Driver, S. and Martell, L. (2006), New Labour ( $2^{\text {nd }}$ edn., Cambridge: Polity Press).

Finlayson, A. (2003), Making Sense of New Labour (London: Lawrence and Wishart).

Finlayson, A. (2007), 'From Beliefs to Arguments: Interpretive Methodology and Rhetorical Political Analysis', British Journal of Politics and International Relations, 9 (4), 545-563.

Finlayson, A. (2010), 'Did Blair Advance Social Democracy?' in S. Griffiths and K. Hickson, eds., British Party Politics and Ideology after New Labour (Basingstoke: Palgrave Macmillan), 11-17.

Freeden, M. (1996), Ideologies and Political Theory: A Conceptual Approach (Oxford: Clarendon Press).

Freeden, M. (1999), 'The Ideology of New Labour', Political Quarterly, 70 (1), $42-$ 51.

Freud, D. (2007), Reducing dependency, increasing opportunity: options for the future of welfare to work (London: HMSO).

HC Deb (1997-98) 303, col. 627.

HM Treasury (1997), The Modernisation of Britain's Tax and Benefit System: Number One. Employment Opportunity in a Changing Labour Market (London: HM Treasury).

HM Treasury (2000), The Goal of Full Employment: Employment Opportunity for all throughout Britain (London: HMSO).

HM Treasury and Department for Work and Pensions (2001), The changing welfare state: employment opportunity for all (London: HMSO).

HM Treasury and Department for Work and Pensions (2003), Full employment in every region (London: HMSO). 
HM Treasury, Department for Work and Pensions and Department for Education and Skills (2004), Supporting young people to achieve: towards a new deal for skills (London: HMSO).

Hain, P. (2007), 'Ministerial foreword' in Department for Work and Pensions, Ready for work: full employment in our generation, Cm 7290 (London: HMSO), 3-5.

Hickson, K. (2004), 'Equality' in R. Plant, M. Beech and K. Hickson (eds.), The Struggle for Labour's Soul: Understanding Labour's political thought since 1945 (London: Routledge), 120-136.

Johnson, P. (2001), 'New Labour: a Distinctive Vision of Welfare Policy?' in S. White (ed.), New Labour: The Progressive Future? (Basingstoke: Palgrave), 63-76.

Kenway, P. (2008), Addressing in-work poverty (York: Joseph Rowntree Foundation).

Labour Party (2001), 'Ambitions for Britain: Labour's manifesto 2001.' Available online at: http://www.psr.keele.ac.uk/area/uk/e01/man/lab/lab01.htm (accessed 16 February 2009).

Labour Party (2005), 'Britain forward not back: Labour's manifesto 2005'. Available online at: http://image.guardian.co.uk/sysfiles/Politics/documents/2005/04/13/labourmanifesto.pdf (accessed 16 February 2009).

Landrum, D. (2002), 'Citizenship, education and the political discourse of New Labour', Contemporary Politics, 8 (3), 219-232.

Layard, R. (2001), Welfare-to-Work and the New Deal (London: Centre for Economic Performance).

Major, J. (1996), Speech to the Conservative Party Conference, 11 October, Bournemouth.

Millar, J. (2000), Keeping track of welfare reform: The New Deal programmes (York: York Publishing Services Ltd).

Mulheirn, I. and Menne, V. (2008), The Flexible New Deal: Making it work (London: The Social Market Foundation).

Myers, F. (2000), 'Harold Macmillan's "Winds of Change” Speech: A Case Study in the Rhetoric of Policy Change', Rhetoric and Public Affairs, 3 (4), 555-575.

Office for National Statistics (2009), 'UK productivity closer to leading G7 countries', news release, 18 February. Available online at: http://www.statistics.gov.uk/pdfdir/icpnr0209.pdf (accessed 21 January 2010). 
Organisation for Economic Co-operation and Development (2007), Activating the Unemployed: What Countries Do. Available online at: http://www.oecd.org/dataoecd/2/10/40777063.pdf (accessed 22 January 2010).

Plant, R. (2004), 'Ends, Means and Political Identity' in R. Plant, M. Beech and K. Hickson (eds.), The Struggle for Labour's Soul: Understanding Labour's political thought since 1945 (London: Routledge), 105-119.

Primarolo, D. (2004), 'Foreword from the Paymaster General' in HM Treasury, Department for Work and Pensions and Department for Education and Skills, Supporting young people to achieve: towards a new deal for skills (London: HMSO), 3.

Purdy, D. (2000), 'New Labour and welfare reform' in D. Coates and P. Lawler, eds., New Labour in power (Manchester: Manchester University Press), 181-194.

Scarre, G. (1996) Utilitarianism (London: Routledge).

Scheffler, S. (1988), 'Introduction' in S. Scheffler, ed., Consequentialism and its Critics (Oxford: Oxford University Press), 1-13.

Shaw, E. (2007), Losing Labour's Soul? New Labour and the Blair Government 1997-2007 (London: Routledge).

Slote, M. (1997), 'Virtue Ethics' in M.W. Baron, P. Pettit and M. Slote, eds., Three Methods of Ethics (Oxford: Blackwell Publishers Ltd), 175-238.

Smith, N. and Middleton, S. (2007), A review of poverty dynamics research in the UK (York: Joseph Rowntree Foundation).

Taylor, R. (2007), 'New Labour, new capitalism' in A. Seldon, ed., Blair's Britain, 1997-2007 (Cambridge: Cambridge University Press), 214-240.

Waltman, J. (2009), 'Reformulating Social Policy: The Minimum Wage, the New Deal, and the Working Families Tax Credit' in T. Casey, ed., The Blair Legacy (Basingstoke: Palgrave Macmillan), 122-134. 